\title{
URGENSI PENGETAHUAN KRITIK HADIS BAGI PRAKTISI DAKWAH
}

\author{
Ahmad Khairuddin \\ Fakultas Dakwah dan Ilmu Komunikasi, UIN Antasari, Banjarmasin, Indonesia \\ Email: khairuddinprof@gmail.com
}

\begin{abstract}
This paper is portraying the urgency of hadith criticism influences which consist of many variables that is crucial to any Islamic preachers. Since there are lots of Islamic preachers who have lack of knowledge on the importance of hadith, especially hadith criticism, some of them may fall into citing or quoting recklessly from any hadith and consider it as reference of their preaching. These mistakes will result in a fatal impact in understanding and practicing hadith as mentioned earlier.
\end{abstract}

KEYWORDS Criticism of hadith; Da'wah practitioners

\section{Pendahuluan}

Dalam kajian ilmu hadis ('ulûm al-hadits), kritik hadis atau yang dikenal dengan naqd al-hadîts merupakan salah satu cabang dari pokok-pokok ilmu dirâyah al-hadîts, yaitu suatu ilmu yang membahas pokok-pokok dan kaedahkaedah untuk mengetahui keadaan sanad dan matn hadis, sehingga suatu hadis dapat diketahui sahih dan tidak sahih (daif), atau suatu hadis dapat diterima (maqbûl) ataupun ditolak (mardûd). Dengan kata lain, verifikasi dan pengujian akan kebenaran suatu hadis menjadi pokok atau inti dari epistemologi kajian ilmu hadis.(Hendar Riyadi, 2005)

Untuk itulah keberadaan ilmu kritik hadis (naqd al-hadits) mempunyai peran yang sangat signifikan dalam menjaga kedudukan hadis sebagai sumber ajaran Islam kedua setelah Alquran, dan fungsinya sebagai penjelas (bayân) terhadap ayat-ayat Alquran, baik sebagai tafshîl, taqyîd al-muthlaq, takhshîsh al-'âm dan tafrî', serta sebagai ta'qid (Lihal Muhammad 'Ajjaj al-Khathib,1997), baik sejak zaman Nabi sampai sekarang selama hal itu dipandang sebagai sebuah ijtihad sebagaimana yang dikemukakan oleh al-hakim. Lebih dari itu, keberadaan hadis sebagai sumber ajaran Islam tidaklah sama seperti Alquran yang telah mempunyai jaminan secara eksplisit dari Sang pencipta dalam ayat Alquran.(H.ihat Q.S al-Hujarât: 10), baik pada tingkat kepastian teks (qath'i alwurûd) ataupun pada tingkat kepastian argumentasi (qath'i ad-dilâlah). Atas 
dasar inilah para ulama hadis (muhadditsîn) telah berusaha merumuskan konsep yang bisa menjamin akan otentisitas hadis sebagai hujjah

Pada sisi lain muncul fatwa yang melarang adanya kritik hadis, khususnya setelah terjadi pembukuan atau penyusunan hadis dalam suatu kitab oleh kolektor yang kredibel. Di antara ulama yang menyatakan demikian adalah Syeikh Taqyad-Dîn Abu Amr ibn Shalah asy-Syahrazurî atau yang dikenal dengan Ibn Shalah. Alasan yang menjadi dasar pelarangan itu adalah faktor adanya kelemahan tingkat keahlian, ketiadaan orang yang pantas digelari "hâffizh al-hâdîts" dengan kadar yang kredibilitas yang terpercaya dan lemahnya daya analisis. Dengan istilah lain, pintu ijtihad terhadap kritik hadis tertutup sebagaimana tertutupnya pintu ijtihad dibidang figh pada akhir abad keempat hijriyah.(Hasjim Abbas, 2004)

Fatwa pelarangan yang dikemukakan oleh Ibn Shalah tersebut menimbulkan tanggapan keberatan dari beberapa kalangan ulama hadis (muhadditsîn), semisal: Muhyy ad-Dîn an-Nawâwî, Zayn ad-Dîn al-'Iraqî, Ibn Hajar al-Asqalani, ash-shan'ânî dan lain-lain. Alasan mereka menolak fatwa tersebut karenar hadis yang terseleksi masih sedikit dibandingkan dengan hadis yang tersebar dikalangan muhaddtsîn. Belum meratanya pemilahan hadis, serta pengaruh polemik antar golongan yang mutasyaddid, mutasahhil, dan mutawassith dalam menentukan kualitas hadis, terutama yang berkaitan dengan sanad. Adanya istilah-istilah rangkap seperti shahîh hasan sebagaimana yang dikemukan oleh Imâm at-Turmudzî, sehingga terkesan adanya keterbukaan untuk meneliti kembali kualitas suatu hadis. Adanya subyektifitas dalam penilaian seorang perawi hadis dan masih bisa mengalami perubahan.(Hasjim Abbas, 2004)

Tulisan ini berusaha untuk menyajikan tentang sejarah dan metodologi kritik hadis yang memuat kajian tentang pengertian kritik hadis, latar belakang pentingnya kritik hadis, sejarah dan perkembangan kritik hadis, metodologi kritik hadis yang dihubungkan dengan urgensi tentang hal-hal tersebut bagi praktisi dakwah dan kesimpulan.

\section{Kajian Teori}

\section{Pengertian Kritik Hadis (Naqd al-Hadîts)}

Secara bahasa kata kritik itu diterjemahkan dengan menghakimi, membanding dan menimbang. Dalam pengertian bahasa Indonesia kata "kritik" dapat diartikan sebagai sifat tidak cepat percaya, tajam dalam menganalisa dan ada uraian pertimbangan baik buruk pertimbangan suatu karya, atau usaha untuk membedakan antara benar dan salah. Dalam bahasa Arab istilah kritik dikenal dengan naqd dan bersinonim dengan kata tamyîz yang berarti penelitian, analisis, pengecekan, dan pembedaan.(Hasjim Abbas, 2004) Atas 
dasar inilah kritik (naqd) dapat disamakan pengertiannya dengan penelitian.

Menurut istilah naqd menurut Ibn Hatim ar-Râzî sebagaimana yang dikutip oleh M. M. al-A'zhami (1982) adalah:

"Upaya menyeleksi (membedakan) antara hadis sahih dan dhaif dan menetapkan status perawi-perawinya dari segi kepercayaan atau cacat".

Sedangkan naqd sebagai pengertian disiplin ilmu kritik hadis adalah: "Penetapan status cacat atau adil pada perawi hadis dengan menggunakan idiom khusus berdasarkan bukti-bukti yang mudah diketahui oleh para ahlinya, dan mencermati matn-matn hadis sepanjang sahih sanad-nya untuk tujuan mengakui validitas atau menilai lemah, dan upaya menyingkap kemusykilan pada matn hadis yang sahih serta mengatasi gejala kontradiksi antar main, dengan mengapliksikan tolak ukur yang detail".(M. Thâhir al-Jawâbî, 1986)

Berdasarkan definisi di atas, kritik hadis pada dasarnya tidak digunakan untuk menilai suatu kebenaran sabda Rasulullah, tetapi untuk mengetahui tentang perangkat yang memuat informasi tentang beliau, termasuk dalam ruang lingkup uji kredibilitas pembawa berita.

\section{Hasil Penelitian dan Pembahasan}

\section{Latar Belakang Pentingnya Kritik Hadis}

Ada beberapa faktor yang menyebabkan kritik hadis merupakan suatu yang mesti dilakukan atau suatu kajian yang sangat urgen dalam ilmu hadis, yaitu:

1. Hadis sebagai sumber ajaran Islam

Dalam mendefinisikan makna hadis, para ulama sangat beragam, misalnya ulama hadis (muhaddisûn). Mendefinisikan hadis sebagai segala sesuatu yang disandarkan kepada Nabi saw, baik perkataan, perbuatannya, ketetapannya dan seluruh keadaannya, karena Nabi adalah contoh teladan yang baik. Ahl ushûl al-fiqh berpendapat bahwa hadis adalah sesuatu yang berasal dari Nabi saw yang berkaitan dengan hukum. Sedangkan menurut ulama fiqih (fuaqhâ), hadis adalah sebagai sesuatu yang berkaitan dengan perincian hukum syar'i, seperti, wajib, sunat, makruh, haram dan mubah.(Muhammad 'Ajjâj al-Khatîb)

Perbedaan itu disebabkan oleh adanya perbedaan dalam memandang hadis sebagai sumber ajaran Islam baik dari aspek hukum ataupun moral agama. Bagi para pakar ushûl al-fiqh. Mereka memandang bahwa perkataan, perbuatan dan penetapan beliau dapat dijadikan sumber hukum, tidak dengan sifat-sifat beliau. Sedangkan bagi ulama hadis (muhadditsîn) memandang bahwa Nabi adalah figur seorang pemimpin dan pemberi petunjuk kepada umat manusia, maka perbuatan, perkataan, 
ketetapan dan sifat-sifatnya dapat dijadikan contoh teladan, baik berkaitan dengan hukum atau tidak.(Ali Mustafa Yaqub, 2004)

Terlepas dari perbedaan itu, hadis menduduki peran yang sangat signifikan sebagai sumber ajaran Islam kedua setelah Alquran, baik secara secara struktural ataupun fungsional. Secara struktural hadis sebagai dasar hukum kedua setelah Alquran, sedangkan secara fungsional hadis sebagai penjelas (bayân) terhadap ayat-ayat Alquran yang bersifat umum. Di samping itu, keberadaan hadis tidak mendapat jaminan dari Allah secara eksplisit sebagaimana Alquran. Baik dari wurûd dan dilâlah-nya.(Said Agil Husin al-Munawwar, 2004) Atas dasar inilah pentingnya melakukan kritik hadis atau penelitian terhadap hadis.

2. Hadis tidak seluruhnya tertulis pada zaman Nabi.

Adanya larangan dan kebolehan penulisan hadis menyebabkan tidak tertulisnya seluruh hadis pada zaman Nabi. Akan tetapi perlu untuk dicermati bahwa penulisan itu telah ada sejak zaman Nabi, seperti suratsurat yang ditulis oleh Nabi kepada para raja sebagai dakwah untuk mengajak agar memeluk Islam.(Arifudditi Ahmad, 2005)

Di samping itu juga ada beberapa sahabat yang menulis atas dasar inisiatif sendiri. Di samping itu, hadis yang tersebar lebih banyak diriwayatkan secara hapalan dari pada tulisan, sehingga menyebabkan penulisan hadis secara tertulis belum mencakup seluruh hadis. Tidak semua hadis yang dicatat para sahabat dengan inisiatif sendiri telah dilakukan pemeriksaan di hadapan Nabi saw., atas alasan inilah pentingnya kritik hadis yang bertujuan untuk memilah hadis sahih dan daif.(Arifudditi Ahmad, 2005)

3. Interval waktu penulisan hadis setelah Nabi wafat

Adanya perbedaan pendapat tentang larangan dan kebolehan menulis hadis pada awal-awal Islam, berimplikasi proses penghimpunan dan pembukuan hadis. Perbedaan itu juga mengakibatkan sebagian periwayat hadis tidak mencatat hadis, hanya menggunakan hapalan semata, sebagian lain ada yang mencatat yang kemudian setelah hapal dihapus, dan ada yang melakukan pencatatan yang bersifatpribadi.(M. Syuhudi Ismail, 1988)

Niat penghimpunan dan penulisan hadis ini telah ada sejak masa khalifah 'Umar ibn al-Khaththâb. Akan tetapi niat tersebut dibatalkan karena adanya kekhawatiran akan mengabaikan Alquran. Barulah pada masa pemerintahan 'Abd al-'Aziz ibn Marwân ketika menjabat sebagai gubernur Mesir niat itu terealisasi yang kemudian resmi dilakukan oleh putranya 'Umar ibn 'Abd al- 'Azîz. Pernyataan seperti ini bukan menunjukkan bahwa penulisan hadis tidak pernah terjadi sebelumnya, akan tetapi penulisan itu 
telah ada sejak zaman sahabat dan tabi'in yang hanya bersifat pribadipribadi, tidak seperti zaman 'Umar ibn 'Abdal-'Aziz yang secara resmi.(M. Syuhudi Ismail, 1988)

Salah seorang ulama hadis yang telah berhasil melaksanakan perintah itu adalah Munammad ibn Muslim ibn Syihab az-Zuhrî, seorang ulama terkenal dari negeri Syam dan Hijaz. Dengan demikian Jarak interval waktu penghimpunan hadis dan kewafatan Nabi saw. cukup lama. Oleh sebab itulah untuk menghindarkan dari penggunaan dalil hadis yang tidak dapat dipertanggungjawabkan validitasnya, maka diperlukan suatu kritik hadis.(M. Syuhudi Ismail, 1988)

4. Timbulnya pemalsuan hadis

Para ulama berbeda pendapat tentang latar belakang awal mula lahirnya hadis palsu. Menurut A $\underline{h}$ mad Amîn - sebagaimana yang dikutip oleh Said Agil Husin al-Munawwar - menyatakan bahwa la telah lahir sejak masa Nabi. Hal ini dibuktikan dengan adanya ancaman dari Nabi terhadap orang yang mendustakan atas nama dirinya. Akan tetapi pendapat tersebut tidak mempunyai fakta historis dan hanya merupakan dugaan dari makna implisit sebuah hadis.(Said Agil Husin al-Munawwar, 2003)

Pendapat lain mengatakan bahwa pemalsuan hadis terjadi pada masa kekhalifahan 'Alî ibn Abû Thâlib, yaitu ketika terjadi pertentangan antara khalifah dengan gubernur Syam, Mu'âwiyah ibn Abû Sufyân. Pertentangan itu terjadi setelah adanya tahkîm sehingga mereka saling mengalahkan, salah satu senjata yang mereka gunakan adalah membuat hadis palsu sebagai upaya untuk menjustifikasi terhadap paham mereka masingmasing. Hal itu disebabkan oleh adanya pertentangan politik dan teologis, serta adanya musuh-musuh Islam yang berusaha untuk merusak ajaran Islam dengan membuat hadis palsu.(Said Agil Husin al-Munawwar, 2003)

Adapun faktor-faktor yang melatar belakangi pembuatan hadis palsu adalah: membela kepentingan politik, membela aliran teologi, membela mazhab fiqh, memikat hati orang yang mendengarkan kisah yang dikemukakan, menjadi orang lain lebih zâhid, menjadikan orang lain rajin mengamalkan ibadah. Menerangkan keutamaan surah dalam Alquran, memperoleh perhatian dan pujian dari penguasa, dan lain-lain.(M. Syuhudi Ismail)

Dengan demikian hadis palsu itu muncul atau dilatarbelakangi oleh kepentingan politik, usaha yang dilakukan musuh Islam, memberikan motivasi dan sugesti untuk beramal dan beribadah, upaya untuk memperoleh kepantingan duniawi dan pemalsuan yang dibuat dengan tidak sengaja.(Said Agil Husin al-Munawwar) 
Untuk memisahkan antara hadis sahih dan palsu, para ulama telah bersusah payah membuat kaedah-kaedah hadis yang dapat diterima dan dapat dijadikan hujjah. Oleh sebab itulah kedudukan kritik hadis sangat penting untuk membersihkan hadis-hadis Nabi dari noda-noda pemalsuan yang dilakukan oleh orang-orang yang tidak bertanggungjawab, sehingga hadis Nabi tidak tercampur dengan sesuatu yang bukanhadis.

5. Banyaknya kitab hadis dengan metode penyusunan yang beragam

Jumlah kitab hadis yang telah disusun oleh oleh para ulama periwayat hadis cukup banyak, sangat sulit dipastikan jumlahnya sebab mukharrij alhadîts tidak terhitung jumlahnya. Hal itu disebabkan bahwa yang ditekankan dalam kodifikasi hadis bukan metode penyusunannya, tetapi upaya penghimpunan hadis-hadis yang masih tersebar di kalangan ulama hadis.(M. Syuhudi Ismail, 1989)

Upaya kodifikasi itu telah menghasilkan berbagai macam kitab hadis dengan metode sendiri-sendiri, baik dalam penyusunan sistematikanya dan topik yang dikemukakan oleh hadis yang dihimpunnya, maupun kriteria kualitas hadisnya masing-masing, atas dasar inilah sehingga sangat wajar para ulama mengklasifikasikan kitab-kitab ke dalam bentuk peringkatperingkat.(M. Syuhudi Ismail, 1989)

Dengan keragaman kriteria terhadap hadis-hadis yang dihimpun dalam kitab-kitab tersebut. Maka kualitas hadis pun akan sangat beragam. Untuk mengetahui kualitas hadis-hadis tersebut. Sahih atau tidak, maka diperlukan kegiatan kritik hadis agar dapat menghindari dari penggunaan dalil hadis yang tidak memenuhi kriteria sebagai hujjah. Lebih dari itu, kualitas para perawi yang termuat dalam berbagai sanad bermacammacam, ada yang memenuhi syarat dan ada yang tidak, hal ini berdasarkan kaedah jarh dan ta'dîl yang digunakan ulama dalam menilai seorang perawi. Di samping itu adanya istilah rangkap yang masih digunakan dalam kitabkitab hadis, sehingga mengesankan sikap keterbukaan untuk melakukan kritik hadis.

\section{Terjadinya periwayatan secara makna}

Dalam sejarah perkembangan hadis, periwayatan hadis pada zaman Nabi saw. umumnya berlangsung secara lisan atau hapalan. Hadis Nabi yang dimungkinkan diriwayatkan secara lafal adalah hadis yang dalam bentuk perkataan, sedangkan dalam bentuk yang lain hanya dimungkinkan diriwayatkan secara makna.(M. Syuhudi Ismail)

Keberadaan hadis dengan periwayatan secara makna menimbulkan pro dan kontra. Misalnya 'Umar ibn al-Khaththâb yang melarang periwayatan secara makna. Pendapat ini Juga didukung oleh Zayd ibn Arqâm dan 'Abd Allâh ibn 'Umar ibn al-Khaththab. Akan tetapi, sebagian ulama ada yang membolehkan periwayatan secara makna dengan beberapa 
syarat tertentu yang cukup ketat, misalnya periwayat yang bersangkutan harus mempunyai pengetahuan yang mendalam tentang bahasa, hadis bersangkutan tidak dalam masalah ta'abbudî, dan periwayatan secara makna dilakukan karena sangat terpaksa.(M. Syuhudi Ismail)

Kebolehan itu menunjukan bahwa periwayatan hadis secara makna telah ada dan sudah banyak. Di sisi lain, untuk mengetahui kandungan hadis tertentu diperlukan terlebih dahulu pengetahuan susunan redaksi (tekstual) dari hadis yang bersangkutan, khususnya hadis yang berkaitan dengan qawli. Untuk itulah kegiatan kritik hadis menjadi sesuatu yang sangat penting untuk menjaga otentisitas hadis. Akibat dari periwayat secara makna tidak hanya menyebabkan perbedaan redaksi semata, tetapi menyebabkan perbedaan kata- kata. Karena suatu kata tertentu dapat saja berbeda ketika hadis yang dibukukan dalam kitab dengan ketika hadis diwurud-kan pada zaman Nabi saw.(M. Syuhudi Ismail)

Dengan demikian adanya periwayatan secara makna menjadi alasan atau faktor pentingnya penelitian hadis atau kritik hadis. Akan tetapi M. Quraish Shihab menolak studi filologi sebagai upaya untuk mengetahui kesahihan hadis. Hal itu disebabkan, hadis kebanyakan diriwayatkan secara makna. Sehingga kata yang digunakan Nabi ketika menyampaikan hadis boleh jadi tidak digunakan pada waktu itu dan digunakan pada masa sesudahnya.(M. Quraish Shihab, 1996)

Di samping ada beberapa alasan sehingga kritik hadis perlu untuk dilakukan. yaitu; motivasi agama sebagai upaya untuk menjaga sunnah dan melestarikannnya, motivasi kesejarahan yang didasari bahwa hadis merupakan peninggalan yang sangat berharga, keterbatasan hadis yang diriwayatkan secara mutâwalir, tidak adanya korelansi kesahihan sanad dan matn, banyaknya hadis yang mempunyai tema dan konsep yang sama, upaya penerapan konsep doktrinal hadis dan beberapa faktor lain yang masih terbuka.(Hasjim Abbas)

\section{Sejarah dan Perkembangan Kritik Hadis}

1. Kritik hadis pada masa Nabi saw

Sejarah kritik hadis telah terjadi sejak Nabi masih hidup. Akan tetapi sifat dari kritik hadis yang diterapkan masih bersifat konfirmasi, klarifikasi dan upaya memperoleh validitas keterpercayaan. Kritik bersifat konfirmasi, yaitu upaya untuk menjaga kebenaran dan keabsahan berita. Sebagai contoh tentang kejadian seorang laki-laki yang mengaku telah membawa pesan Nabi untuk singgah dirumah siapa saja untuk membuat perhitungan hukum sendiri. Akan tetapi itu tidak benar. (Hasjim Abbas)

Kritik dengan sifat klarifikasi (tabâyun), yaitu upaya menyelaraskan dan mencari penjelasan lebih konkret. Misalnya tentang kejadian laporan Wâlid ibn 'Uqbah yang ketika ta ditugaskan menjadi amil shadaqah pada 
Banû Mushthalaq, dan ketika itu mereka menyambut dengan persenjataan karena Wâlid pernah terlibat peperangan dengan mereka sebelumnya, sehingga Wâlid mengatakan kepada Nabi bahwa mereka telah melakukan jebakan kepadanya, Sehingga membuat Nabi percaya.(Hasjim Abbas)

Kritik dengan sifat mengusahakan kesaksian dan pembuktian atas sesuatu yang diduga sebagai perbuatan Nabi saw. dan yang terakhir adalah kritik hadis dengan orientasi kepada kritik main (kandungan) suatu hadis. Tujuannya adalah untuk esensi faktanya yang dilaksanakan dengan menyelidiki lokasi kejadian, bertemu langsung dengan subjek narasumber serta melibatkan peran aktif pribadi Nabi.(Hasjim Abbas)

2. Kritik hadis pada masa sahabat

Kritik hadis yang diterapkan pada masa sahabat hanya mengarah kepada kedhâbith-an semata, tidak pada aspek al-'adâlah, karena pada dasarnya seluruh sahabat adalah 'udul dan terkenal kejujurannya, sehingga kritik terhadap sanad tidak terlihat disamping karena jarak yang tidak terlalu banyak. Tradisi kritik yang diterapkan para sahabat dengan cara saling menegur dan mengingatkan yaitu, perbaikan kesalahan ketika mendengar pemberitaan yang menunjukkan bias informasi, dan sahabat yang lebih tahu langsung menanggapi dan meluruskannya.(Al-Jawâbi)

Motif utama penerapan kritik hadis pada masa sahabat adalah dalam rangka melindungi agar tidak terjadi kedustaan atas nama diri Rasulullah. Kaedah kritik lebih tertuju kepada uji kebenaran bahwa Rasulullah saw jelasjelas menginformasikan hadis itu. Prosedurya dengan cara membandingkan (muqâranah) atau mendapatkan informasi dengan jalan silang antara riwayat dari sesama sahabat, karena dimungkinkan adanya kemiripan kalimat atau hanya semakna saja atau dengan istilah lain setiap hadis yang diriwayatkan harus dibuktikan dengan kesaksian minimal dua orang, dan hal inilah yang diterapkan oleh para khalifah yang empat.(Hasjim Abbas)

Di samping menggunakan metode perbandingan, digunakan juga metode pencocokan (mu'âradhah) yaitu dengan memcocokkan konsep yang menjadi muatan pokok setiap matn hadis. Metode pencocokkan ini dengan langkah merujuk kepada petunjuk Alquran yang bersifat eksplisit. Dengan hadis yang semakna, pengetahuan kesejarahan dan penalaran akal sehat. Dengan demikian kritik yang diterapkan oleh para sahabat lebih banyak menekankan pada aspek matn tidak pada sanad.(Mid. h.)

3. Kritik hadis pada masa muhâddtsîn

Banyaknya bermunculan hadis-hadis palsu membangkitkan semangat para ulama hadis untuk melambagakan sanad sebagai upaya 
untuk menjaga otentisitas hadis, karena pada dasarnya kritik yang dilakukan pada masa Nabi atau sahabat masih berorientasi pada matn. Akan tetapi untuk mewaspadai gejala pemalsuan dengan menelaah terhadap sanad dan mencermati integritas keagamaan periwayat telah berlangsung pada masa sahabat kecil.(Mushthafa as-Siba'l, 1996)

Walaupun demikian, pelambangan sanad belum menjadi keharusan, karena masih ditemukannya periwayatan hadis dengan cara mursal. Yakni tidak menyertakan dengan jelas dari jalur sahabat yang mana dia mengambil. Baru ketika pertengahan abad kedua hijriyah keberadaan sanad merupakan suatu yang tidak bisa ditawar lagi, sehingga hadis yang tidak mempunyai sanad yang sahih akan ditolak.(Al-Jawfib)

Kesungguhan para ulama dalam mencermati sanad dan integritas keagamaan serta kredibilitas seorang perawi melahirkan ilmu yang dikenal jarh wa ta'dîl (mencermati kecacatan dan keterpujian pribadi seorang perawi). Sedangkan biodata pribadi periwayat hadis yang ditelusuri meliputi: data kelahiran dan wafatnya, tempat tinggal, kegigihan dalam mencari hadis, nama guru dan murid, penilaian kritikus tentang integritas keagamaan dan indikasi tersangkut paham bid'ah, kekuatan hapalan atau catatan dan tingkat generasi dalam dalam kehadisan.(Al-Jawfib) Pada masa inilah penerapan metode pencocokan semakin ditingkatkan, sehingga pada masa inilah dikenal dengan kritik sanad dan kritik matn.

Pada perkembangan selanjutnya kritik hadis bergerak mengikuti dinamika keilmuan dan kecenderungan pemerhati hadis. Misalnya, seorang yang ahli dalam bidang bahasa, maka ia akan mencermati dan memperbandingan bahasa, gaya bahasa hadis yang bersifat qawlî, dan membandingkan dengan penuturan kata-kata yang digunakan Nabi pada setiap hari. Ulama hadis yang menguasai tentang ilmu hadis secara mendalam khususnya tentang doktrinal hadis akan membandingkan dengan sesama hadis dan dengan Alquran. Masih banyak lagi, seperti ulama kalam yang banyak melihat hadis pada masalah-masalah yang sifat-sifat Allah dan alam gaib, ulama fiqh mencermati hadis dari segi pembinaan dan penerapan syari'at. Dan kritikus terakhir sibuk merespon sikap keraguraguan hadis baik yang datang dari orang Islam itu sendiri maupun dari kalangan orientalis.(Al-Jawfib) Pada masa ini adanya pemetaan hadis dalam tema-tema tertentu dan tujuan kritik hadis tidak lagi berorientasi untuk memperoleh validitas suatu berita.tetapi sudah kepada tujuan pemikiran diterima (maqbul) atau tidaknya suatu hadis (mardûd).

\section{Metodologi Kritik Hadis}

Metodologi kritik hadis hadis (naqd al-hadîts) dibedakan menjadi dua, yaitu: kritik sanad (kritik ekstemal atau an-naqd al-khârijî) dan kritik matn (kritik 
internal atau an-naqd ad-dâkhilî).

1. Kritik ekstemal atau kritik sanad (an-naqdal-khârijî)

Kritik ekstemal atau kritik sanad (an-naqd al-khârijî) adalah telaah atas prosedur periwayatan (sanad) dari jumlah rawi yang secara runtut menyampaikan matn hingga rawi terakhir. Dalam metodologinya, keabsahan atau otentisitas suatu sanad diukur dengan lima kaedah:

Pertama, sanad-nya harus bersambung (muttasil), menurut M. Husein Yusuf (1996), cara yang ditempuh untuk mengetahui persambungan sanad itu dilakukan melalui:

a) Mencatat semua rawi dalam sanad tersebut,

b) Mempelajari beografi dan aktifitas keiimuansetiapperawi,

c) Meneliti kata-kata yang menghubungkan antara para rawi dengan rawi terdekat dalam sanad seperti kata haddatsanâ, akhbaranâ, anba 'anâ dan lain- lain. Sedangkan keterputusan sanad disebabkan oleh gugurnya perawi, baik pada tingkat tabi'i (mu'alaq), tingkat sahabat (mursal), gugurnya dua rawi secara berujutan (mu'addal) ataupun yang tidak berurutan (munqathi') serta tidak adanya bukti yang menjelaskan bahwa rawi yang menerima hadis tidak pernah berkunjung atau bertemu ke tempat orang yang menyampaikan hadis itu kepadanya.

Kedua, rawinya harus bersifat adil. Menurut M. Husein Yusuf (1996), keadilan seorang perawi ditetapkan dengan:

a) Popularitas keutamaan dan kemuliaanya di kalangan ulama hadis,

b) Penilaian dari para kritikus hadis yang mengandung pengungkapan kelebihan dan kekurangan perawi,

c) Penerapan kaedah jarh wa ta'dil tidak disepakati dalam menilai seorang perawi.

Ketiga, rawinya dhâbith, menurut M. Husein Yusuf (1996) ke-dhâbith-an seseorang dapat diketahui dengan:

a) Kesaksian ulama,

b) Berdasarkan kesesuaian riwayatnya dengan riwayat yang disampaikan oleh rawi lain yang sudah dikenal dengan ke-dhâbithannya, disamping itu hapal dengan baik hadis yang diriwayatkan dan mampu menyampaikan riwayat tersebut kepada orang lain.

Keempat, terhindar dari syâdz. Menurut M. Husein Yusuf (1996), keadaan syâdz atau tidak suatu isnad dapat diketahui dengan cara:

a) semua sanad hadis yang mempunyai pokok masalah yang sama harus 
dibandingkan,

b) Para perawi dari seluruh sanad harus diteliti,

c) Apabila ada satu yang menyalahi dari selumh sanad yang rawinya dinyatakan tsiqah, maka sanad tersebut adalahsyâdz.

Kelima, terhindar dari 'illah. Sanad hadis dianggap cacat terjadi percampuran hadis dengan hadis lain, kesalahan dalam penyebutan rawi yang mempunyai kemiripan. Adapun cacatnya suatu hadis dapat diketahui dari kecerdasan seseorang, Intuisi, hapaian hadis dan kedalaman pengetahuannya tentang berbagai ke-dhâbith-an serta mengetahui tentang sanad dan matn Dengan demikian, hadis apabila telah memenuhi acuan di atas, maka ia dianggap sahih, selama unsur-unsur tersebut diterapkan dengan baik dan cermat.(M. Husein Yusuf, 1996)

\section{Kritik internal atau kritik matn (an-naqdad-dhâkhilî)}

Kritik matn (naqd al-matn, kritik internal) adalah kajian dan pengujian atas keabsahan suatu matn hadis. Adapun kaedahnya, yaitu: terhindar dari syâdzdz dan 'illah.(Muhammad al-Ghazali, 1089) Ulama hadis tampaknya mengalami kesulitan dalam mengemukakan unsur-unsur dan syarat-syarat kritik matn tidak seperti kritik sanad. Pernyataan tersebut tidak bisa ditafsirkan bahwa ulama hadis tidak memiliki sama sekali tolak ukur dalam meneliti matn.

M. Syuhudi Ismail mengutip pendapat ulama hadis tentang tolak ukur kritik matn, yaitu: tidak bertentangan dengan petunjuk Alquran, tidak bertentangan dengan hadis yang lebih kuat, tidak bertentangan dengan akal sehat, susunan pernyataan menunjukan ciri-ciri kenabian dengan sempurnanya formasi kata, kalimat dan makna, dan tidak mempunyai syâdz dan 'illah. Adapun langkah langkah metodologis kritik hadis dilakukan sebagaimana yang dikemukakan oleh M. Syuhudi Ismail - sebagai berikut: meneliti matn dengan memperhatikan sanad-nya, meneliti susunan lafal-lafal berbagai matn semakna, meneliti dengan kandungan Alquran.(M . Syuhudi Ismail)

\section{Urgensi Kritik Hadis bagi praktisi Dakwah}

Bagi seorang praktisi dakwah, mengetahui kritik hadis dan hal-hal yang berhubungan dengan hadis sangat penting. Tanpa mengetahuinya akan menyebabakan sesuatu yang fatal. Praktisi dakwah meyampaikan ajaran agama yang salah satunya bersumber dari hadis, sedangkan hadis tidak semuanya dapat dipertanggungjawabkan berasal dari Nabi saw. Dapat dibayangkan apabila seorang praktisi dakwah menyampaikan semua hadis yang diketahuinya tanpa mengetahui kualitasnya. Hal ini dapat menimbulkan kesalah pahaman dan keyakinan yang mungkin kurang tepat atau bahkan keliru. Dan yang lebih fatal 
akan menghadirkan Islam yang tidak semestinya. Ajaran Islam yang tinggi dan mulia ditutupi oleh pemahaman yang tidak tepat yang dihasilkan oleh praktisi dakwah yang tidak mengerti kritik hadis dan hal-hal yang berhubungan hadis.

\section{Simpulan}

Kritik hadis (naqd al-haqdits) adalah suatu upaya untuk mengetahui kesahihan suatu hadis dengan cara membandingkan atau meneliti dengan dalildalil yang lebih kuat, baik dengan ayat-ayat Alquran ataupun hadis mutâwatir.

Adapun yang melatar belakangi pentingnya kritik hadis adalah: hadis merupakan sumber ajaran Islam, tidak semua hadis ditulis pada masa Nabi dan interval waktu yang cukup lama dalam pembukuan hadis, terjadinya pemalsuan hadis, penyusunan kitab hadis dengan metode yang beragam, dan terjadinya periwayatan secara makna. Alasan lain adalah karena adanya motivasi agama, motivasi kesejarahan, keterbatasan hadis mutâwatir, tidak adanya korelansi kesahihan sanad dan matn, banyaknya hadis yang mempunyai tema dan konsep yang sama, upaya penerapan konsep doktrinal hadis.

Sejarah kritik hadis sudah dimulai sejak Nabi masih hidup. Akan tetapi hanya dalam bentuk konfirmasi, klarifikasi, dan upaya mencari validitas kepercayaan suatu berita. Pada zaman sahabat kritik hadis sudah mulai berkembang, tetapi tidak mengarah kepada kritik sanad, hanya kepada matn saja dengan metode muqâranah dan mu'ârdhah. Selanjutnya pada zaman muhaddîtsin kritik hadis sangat diperlukan, karena banyaknya pemalsuan hadis, pada masa inilah kritik sanad menjadi suatu keharusan disamping kritik matn. Karena itu menjadi sebuah keniscayan bagi seorang praktisi dakwah untuk mengetahui pengetahuan kritik hadis, karena dalam dakwahya ia pasti akan berinteraksi dengan hadis yang menjadi salah satu sumber dakwah yang disampaikannya.

Pada periode inilah kritik hadis tidak lagi sebagai upaya untuk mencari validitas suatu berita, tetapi mengarah dengan tujuan untuk mengetahui hadis diterima (maqbûl) dan ditolak (mardûd).

Metodologi kritik hadis, yang diterapkan oleh ulama hadis dapat digolongkan kepada dua, yaitu kritik sanad atau eksternal (an-naqd al-khâriji) dan kritik matn atau intemal (an-naqd ad-dâkhili) dengan menggunakan kaedahkaedah yang telah ditetapkan oleh para ulama.

\section{Referensi}

Abbas, Hasjim. 2004. Kritik Matan Hadis Versi Muhadditsin dan Fuqaha. Yogyakarta: Teras Al-A'zhami, M. Mushtafa. 1982. Manhaj Naqd 'ind al-Muhqdditsin. Riyâdh: al- Ummariyah Al-Ghazâlî, Muhammad. 1989. As-Sunnah an-Nabawiyyah bayn Ahl al-Fiqh wa Ahl al- $\underline{\text { Hadits }}$ cet ke-6. Al-Qahirah: Dâr asy-Syurûq

Al-Jawâbi, M. Thâhir. 1986. Juhûd al-Muhâadditsîn fi Naqd Main al-Hâdits an- Nabawiyyah asy-Syarif. Tunisia: Muassasah 'Abd al-Karim

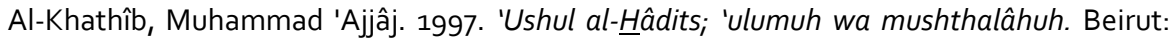




\section{Daral-Fikr}

Ahmad, Arifuddin. 2005. Paradigma Memahami Hadis Nabi. Jakarta: Renaisan

As-Sibâ'i, Mushthafâ. 1996. As-Sunnah wa Makânatuhâ fi Tasyri' al-lslâmi. Damaskus: Diir al-Qawmiyyah

Bustamin - M. Isa H. A. Salam. 2004. Metodologi Krilik Hadis. Jakarta: Raja Grafindo Persada Husin al-Munawwar dan Said Agil. 2003. Al-Qur'an Membangun Tradisi Kesalehan Hakiki. Jakarta: Ciputat

llyas, Yunahar dan M. Mas'udi (ed). 1996. Pengembangan Pemikiran Terhadap Hadis. Yogyakarta: L P P I - U M Y

Ismail, M. Syuhudi. 1988. Kaedah Kesahihan Sanad Hadis: Telaah Kritis dan Tinjauan dengan Pendekatan Ilmu Sejarah. Jakarta: Bulan Bintang

M. Syuhudi. 1989. Metodologi Penelitian Hadis Nabi. Jakarta: Bulan Bintang

Riyadi, Hendar. 2005. Tafsir Emansipatoris: Arah Baru Studi Tafsiral-Qur'an. Bandung: Pustaka setia

Said Agil, dan Abdul Mustaqim. 2004. Asbabul Wurud: Sludi Kritis Hadits Nabi dengan Pendekatan Sosio-Historis-Kontekstual. Yogyakarta: Pustaka Pelajar

Yaqub, Ali Mustafa. 2004. Krilik Hadis cet ke. 4. Jakarta: Pustaka Pirdaus 